\title{
Regulation of population density of symbiotic algae in a tropical marine jellyfish (Mastigias sp.)
}

\author{
L. Muscatine ${ }^{1}$, F. P. Wilkerson ${ }^{1, *} \&$ L. R. McCloskey ${ }^{2}$ \\ ${ }^{1}$ Department of Biology, University of California, Los Angeles, California 90024, USA \\ ${ }^{2}$ Department of Biological Sciences, Walla Walla College, College Place, Washington 99324, USA
}

\begin{abstract}
Marine jellyfish Mastigias sp. are abundant in marine lakes in Belau. Western Caroline Islands. They contain symbiotic dinoflagellates (= zooxanthellae) in cells of the mesoglea. The population density of zooxanthellae was measured as a function of host size and found to be sizeindependent, suggesting that it is regulated. To determine how population density might be regulated, specific growth rates of algae $\left(\mu_{z}\right)$ and host $\left(\mu_{a}\right)$ were measured independently as a function of host size. The rates were dissimilar with $\mu_{z}$ less than $\mu_{a}$ in small medusae and $\mu_{z}$ greater than $\mu_{d}$ in large medusae. Maintenance of medusae under laboratory conditions resulted in transient increases in $\mu_{2}$ in small medusae up to 7 times greater than normal, suggesting that zooxanthellae in small medusae are capable of facultative increase in specific growth rate, thereby sustaining normal population density. The general conclusion drawn is that zooxanthellae population density is maintained in small medusae by facultative, transient increase in $\mu_{2}$ and in large medusae by expulsion and/or digestion of zooxanthellae. Factors which regulate zooxanthellae growth rate are not yet known.
\end{abstract}

\section{INTRODUCTION}

Symbiotic dinoflagellates (= zooxanthellae) inhabit a wide range of tropical marine cnidarians (corals, sea anemones, gorgonians, etc.) (McLaughlin \& Zahl 1966). They comprise from 3 to $23 \%$ of the protein biomass of a given association (Muscatine 1980), and although their specific growth rate is potentially greater than that of the host (Droop 1963), their population densities are relatively constant. That zooxanthellae do not overgrow their hosts is de facto evidence for regulation. Of interest is the mechanism by which zooxanthellae population density might be controlled.

Droop (1963) characterized, in a general way, the major elements involved in regulation of population density of symbiotic algae. He reasoned that (p. 178) 'once established in the host, the algae increase in numbers, but only until they reach the population density approprate to the situation... Thereafter the numbers are maintained at this level by some process of regulation, dynamic stability being one of the features of symbiosis... The alga should have as high a potential specific growth rate as the animal tissue it

- Present address: Allan Hancock Foundation, University of Southern California, Los Angeles, California 90089, USA inhabits... Control may also be effected by digestion...

From Droop's characterization, it follows that to maintain a constant population density, the in situ growth rate of the algae must be equal to or greater than the growth rate of a given host. If greater, then algae in excess of the host carrying capacity are presumably expelled or digested. Thus, by measuring growth rates of symbiotic algae and host independently, one can determine if they are growing at the same rate, and if not, whether the algae are prone to regulation by expulsion and/or digestion. Using this approach, Muscatine et al. (1985) found that specific growth rates of zooxanthellae in the Red Sea coral Stylophora pistillata were 3 to 9-fold greater than host specific growth rates, depending on host size. Since Hoegh-Guldberg et al. (unpubl.) found little evidence for release of zooxanthellae from S. pistillata, digestion of zooxanthellae emerged as a potential mechanism for regulating population density.

Virtually all existing information on zooxanthellae population density comes from studies of benthic, sessile associations such as sea anemones and corals. There have been very few investigations of pelagic, mobile algae-cnidarian symbioses, such as marine jellyfish. Ready access to $1.61 \pm 0.17$ million symbiotic 
medusae (Mastigias sp., Cnidaria; Rhizostomae) in Eil Malk Jellyfish Lake, Republic of Belau (formerly Palau), Western Caroline Islands (Hamner \& Hauri 1981) provided a unique opportunity to study field populations. Unlike benthic sessile symbioses, the ability of Mastigias sp. medusae to maximize exposure to sunlight by swimming horizontally in shallow water during the day (Hamner \& Hauri 1981, Hamner et al. 1982) and to maximize exposure to inorganic nutrients by swimming to the lake chemocline at night (Muscatine \& Marian 1982), makes them novel subjects for investigation of zooxanthellae productivity and regulation of zooxanthellae population density.

The purpose of the present study was to characterize zooxanthellae population density in Mastigias sp. as a function of host size, and to measure specific growth rates of zooxanthellae and medusae independently to gain insight into how population density might be controlled. Observations on the fine structure of the loci of algae in Mastigias sp. are also presented.

\section{METHODS}

All experiments were carried out at the Micronesian Mariculture Demonstration (MMDC) or Eil Malk Jellyfish Lake, Belau, Western Caroline Islands, during February and March 1982. Some analytical procedures (SEM, TEM) were carried out at the University of California, Los Angeles, USA.

Mastigias sp. were collected at Eil Malk Lake and maintained at the MMDC as described by Muscatine \& Marian (1982). Unlike most scyphomedusae, the ephyrae of Mastigias sp. from Eil Malk Lake are recruited throughout the year, and there are no pelagic predators (Hamner et al. 1982). Thus medusae of all sizes (0.5 to $18.0 \mathrm{~cm}$ ) are always available.

Scanning electron microscopy. Very small specimens (bell diam. 1 to $2 \mathrm{~cm}$ ) were fixed in $5 \%$ formalin in sea water ( $\mathrm{pH} 7.2)$, and dehydrated in a graded series of ethanol. While in $100 \%$ ethanol, specimens were frozen in parafilm tubes in liquid nitrogen, and fractured with a sharp blow from a razor blade taped to a small hammer. Tissue fragments in $100 \%$ ethanol were critical-point dried (Samdri), attached to stubs, sputter-coated with a gold-palladium mixture and viewed with an ETEC scanning electron microscope (10 kV; $20^{\circ}$ tilt).

Transmission electron microscopy. Small specimens were fixed in $4 \%$ formaldehyde and $1 \%$ glutaraldehyde in $0.1 \mathrm{M}$ phosphate buffer according to McDowell (1978). Fixed material was brought back to UCLA, postfixed in $1 \%$ osmium tetroxide in $0.2 \mathrm{M}$ cacodylate buffer ( $\mathrm{pH}$ 7.4), dehydrated in ethanol and embedded in Medcast epoxy resin. Thin sections were cut with glass knives, collected on 200 mesh copper grids coated with carbon and parlodion, stained with uranyl acetate and lead citrate, and examined with a Philips $300 \mathrm{EM}$ at $60 \mathrm{kV}$.

Biomass parameters. Medusa bell diameter, total protein, and numbers of algae were determined as described previously by Muscatine \& Marian (1982).

Zooxanthellae population density. From measurements of total protein in medusa homogenates and estimates of zooxanthellae protein from the same homogenates, algae-medusa protein biomass ratios were established. Zooxanthellae protein in the homogenates was determined from algal size as follows. Diameters of 1000 zooxanthellae from a range of sizes of medusae were measured to the nearest 0.1 um using a calibrated ocular micrometer at $450 \times$. From mean cell diameter the mean volume per cell was computed and the carbon per cell calculated according to Strathmann (1967). From carbon per cell and zooxanthellae $\mathrm{C}: \mathrm{N}$ atomic ratios, we calculated $\mathrm{N}$ per cell; and from $N \times 6.25$, protein per cell.

For algal $\mathrm{C}: \mathrm{N}$ atomic ratios, suspensions of algae were obtained from homogenized medusae as described by Muscatine \& Marian (1982). Six batches of algae were sampled over $24 \mathrm{~h}(1730 \mathrm{~h}, 2200 \mathrm{~h}$, $0600 \mathrm{~h}, 1000 \mathrm{~h}, 1400 \mathrm{~h}$ ) from hosts ranging in size from 9.5 to $12 \mathrm{~cm}$ diameter. Since the algae are located in the mesoglea, and since the host produces negligible mucus, the suspensions were unusually clean and free from contaminating animal material, including nematocysts. Isolated algae were rinsed briefly with fresh water, dried at $60^{\circ} \mathrm{C}$ in a drying oven, and stored with desiccant until analysed with a CHN Analyser at the Institute of Marine Science Analytical Laboratory, University of California, Santa Barbara, California, USA.

Specific growth rates. The specific growth rates of zooxanthellae $\left(\mu_{2}\right)$ in situ were estimated from daily

Fig. 1. Mastigias sp. Scanning electron micrographs. (a) Small Mastigias cryofractured to show cross-section of exumbrellar and subumbrellar epithelia and loci of algal clusters in mesoglea (at arrows). 360x. (b) Same as (a) but higher power view showing representative cluster of zooxanthellae in the mesoglea, sheathed in smooth material and associated with fibers of the mesoglea. Note epitheliomuscular layer of exumbrellar ectoderm. ECT ectoderm; END: endoderm; ZX: zooxanthellae; MES: mesoglea. $1800 \times$ (c) Same as above, showing detail of sheathing and fibers associated with zooxanthellae. $7200 \times$ (d) Cryofracture through folds of coronal muscle on subumbrellar surface showing loci of zooxanthellae (at arrow). $72 \times$. (e) As in (d), higher power showing abundance of zooxanthellae and several smaller entities interpreted as animal cell nuclei (at arrows). 1400x (f) As above, showing detail of sheathing fibers and putative animal cell nucleus (at arrow), $3600 \times$ 


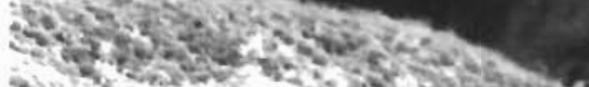

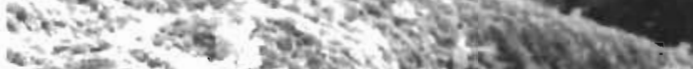

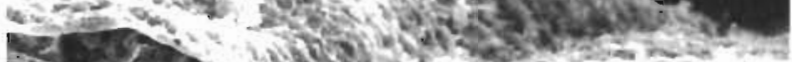

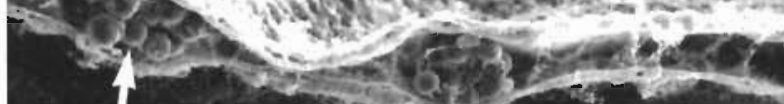

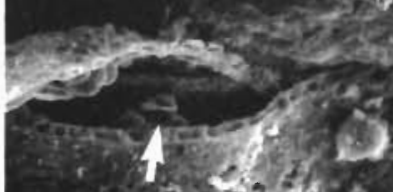

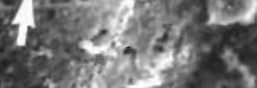

a $x$ \%

a 6 : 3 ,
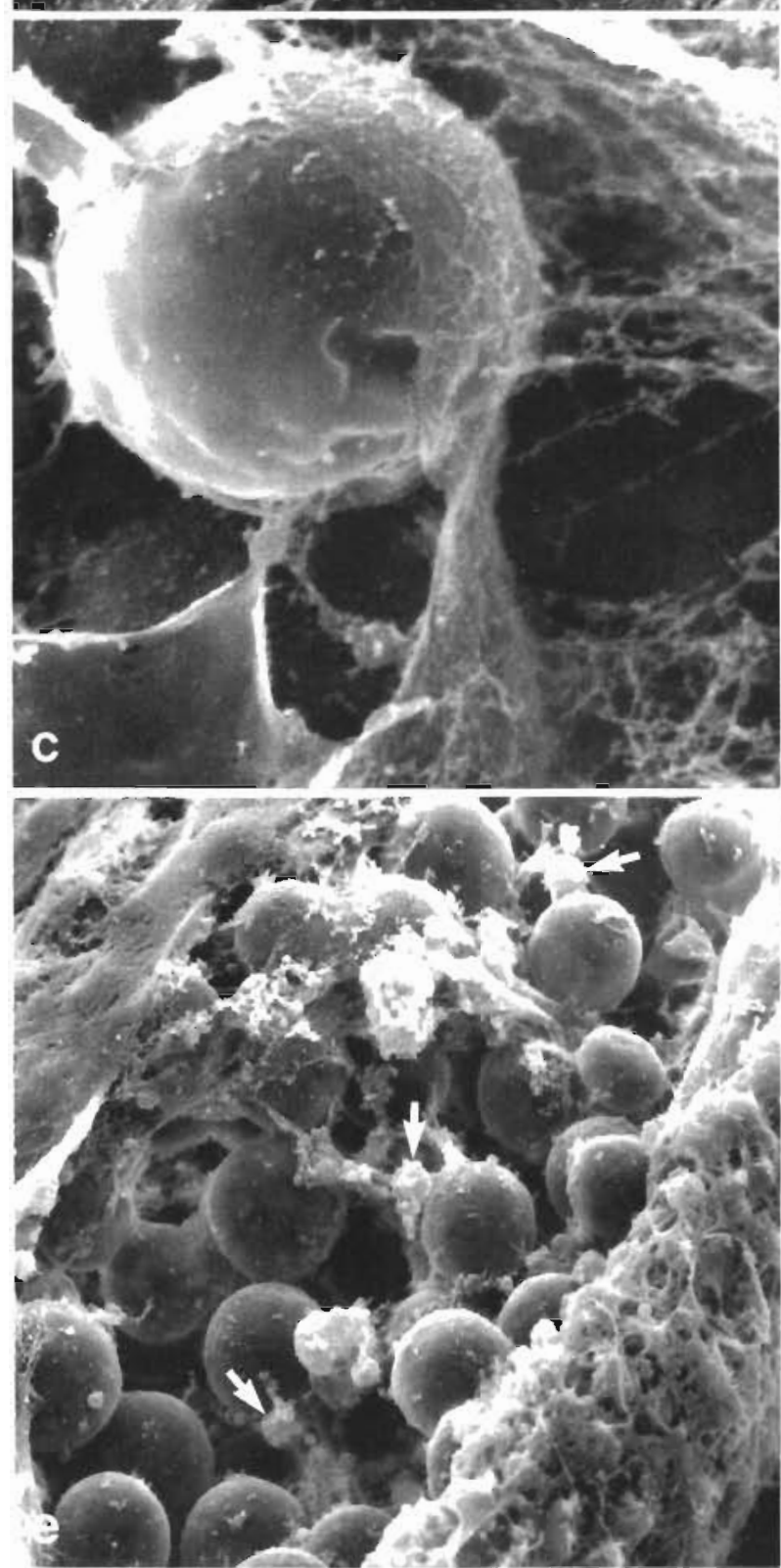

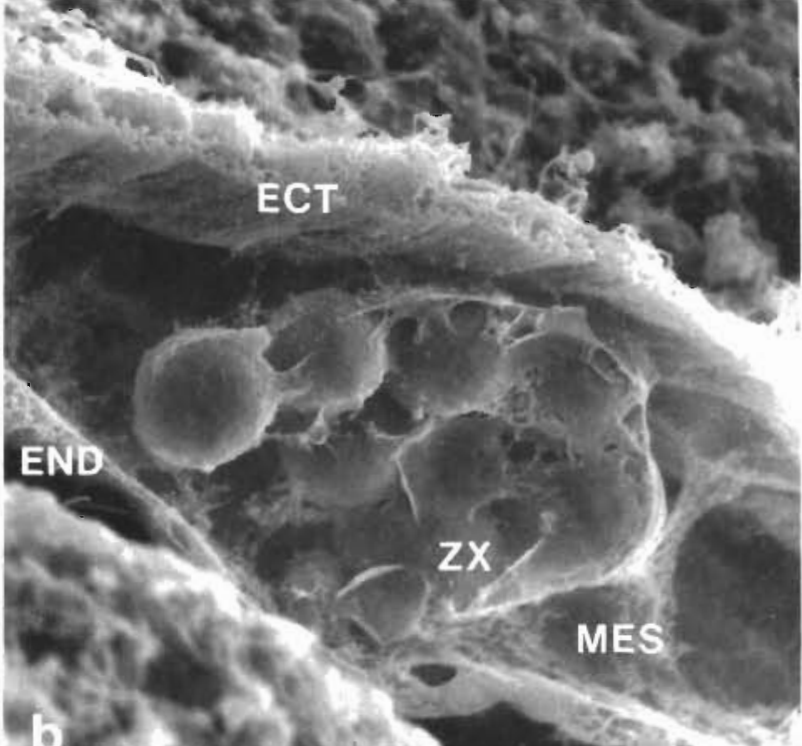

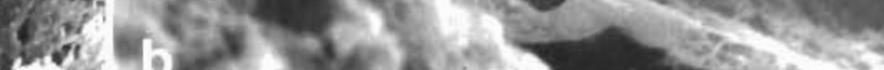

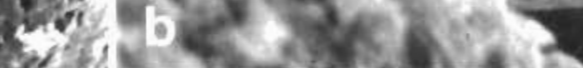
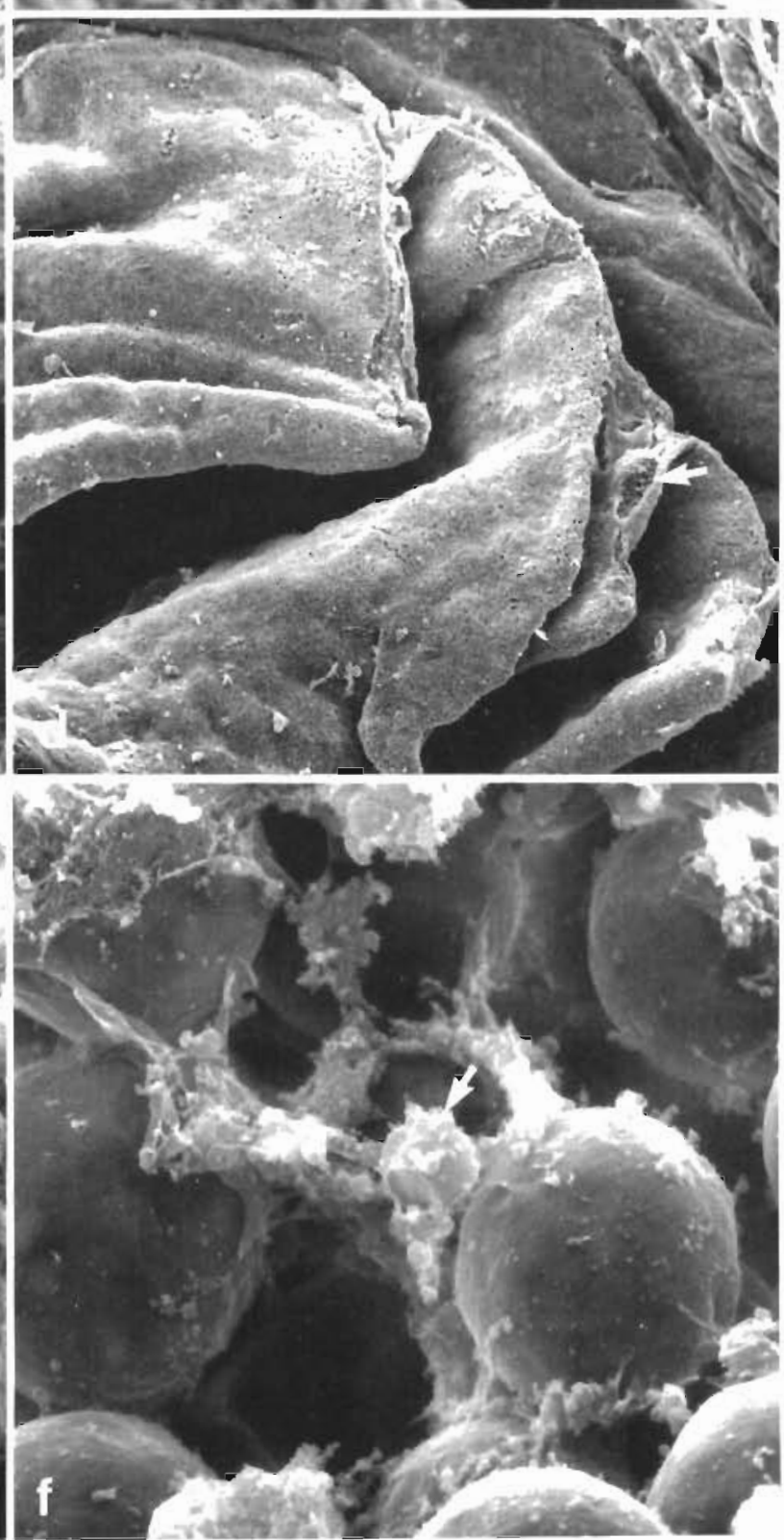
mitotic index (MI) data using the formulae of McDuff \& Chisholm (1982) as described by Wilkerson et al. (1983).

Specific growth rates of medusae $\left(\mu_{a}\right)$ were calculated as described by Muscatine et al. (1985) from data of Sugiura (1963) on diameter of the umbrella (hereinafter called the bell) versus time in days. He collected Mastigias papua L. Agassiz from the vicinity of Misaki Marine Biological Station during July, August, and September 1962, when ephyrae and young medusae first appeared in the water column. Both maximum and mean bell diameters were recorded for medusae freshly collected at specific times over 2 mo. We calculated linear regression constants sequentially for successive pairs of data on age and diameter presented by Sugiura, such that

$$
\text { diameter }=\mathrm{a}+\mathrm{b}(\mathrm{age})
$$

where $\mathrm{a}=$ intercept $\mathrm{b}=$ slope of the regression curve. Using these constants and values of age $+1 d$, we calculated diameter +1 d. Specific growth rates for medusae at each initial age were then computed from

$$
\mu_{\mathrm{a}}=\frac{\text { diam }_{+1 \mathrm{~d}}-\text { initial diam }}{\text { initial diam }}
$$

\section{RESULTS}

\section{Fine structure of the association}

Fig. 1a shows clusters of algae in the mesoglea between the exumbrellar and subumbrellar epithelia. The algae are intimately sheathed and associated with fibers from the collapsed mesoglea (Fig. 1b,c). Algae also occur in dense tracts closely aligned with the coronal muscle bands (Fig. 1d,e). Materials sheathing the algae and occasional presumed animal cell nuclei are evident (Fig. 1f). Transmission electron micrographs of bell tissue confirmed that the algae are within spaces in the mesoglea (Fig. 2), and individually sheathed by several membranes. These membranes are very likely elements of the algal cell including its plasma membrane. The zooxanthellae are interpreted as being intracellular in cells of the mesoglea. If true, it is likely that the membrane outermost to the algae is a host cell vacuolar membrane. The observation of occasional presumed animal cell nuclei adjacent to the algae in some preparations (Fig. 3) is consistent with this interpretation. However, we cannot discern host cell plasma membrane contiguity in our preparations.

\section{Biomass parameters}

To determine if population density of zooxanthellae varied as a function of medusa size, we first determined how zooxanthellae biomass (total numbers, size) and medusa biomass (total protein) changed with respect to medusa bell diameter.

Tables 1 and 2 show that as bell diameter increased, total numbers of algae also increased, as did medusa total protein.

To determine how algal cell size varied with bell diameter, we measured algal cell diameters from medusae of selected sizes. Algae ranged in size from 5 to $13 \mu \mathrm{m}$. Fig. 4 shows that mean zooxanthellae diameter and bell diameter were inversely correlated. Mean algal cell diameters decreased from $9.85 \pm 1.34 \mu \mathrm{m}$ in small medusae to $8.25 \pm 1.25 \mu \mathrm{m}$ in large medusae. From regression data of algal cell size vs bell diameter (Table 2), we calculated zooxanthellae cell diameters for each medusa in Table 1, and from these data, estimated the total algal carbon.

\section{Zooxanthellae population density}

The mean ( \pm SD of mean; $n=6$ ) zooxanthellae $C: N$ atomic ratio was $9.66 \pm 0.43$. There was no evidence of diel variation in $C: N$. Applying this mean ratio to the algal carbon data in Table 1 , we calculated the values for total algal protein. The total algal protein:total medusa protein (including algae) biomass ratios averaged $0.10 \pm 0.03( \pm S D$ of mean; $n=25)$, a value in agreement with previous estimates of Muscatine \& Marian (1982). Regression data in Table 2 show that this expression of weight-specific algal population density does not correlate significantly with host size. From this we infer that weight-specific algal population density is independent of host size. Similarly, algal population density based on number of algae per unit host protein averaged $0.28 \pm 0.08 \times 10^{7}$ cells $(\mathrm{mg}$ protein $)^{-1}$ ( \pm SD of mean; range 0.42 to $0.10 ; \mathrm{n}=25$ ). Since this parameter does not correlate significantly with host size (Table 2), it too is inferred to be independent of host size.

\section{Growth rates}

To gain insight into how zooxanthellae population density might be maintained, we measured specific growth rates of algae independently, and compared them to medusa growth rates as a function of medusa size. 


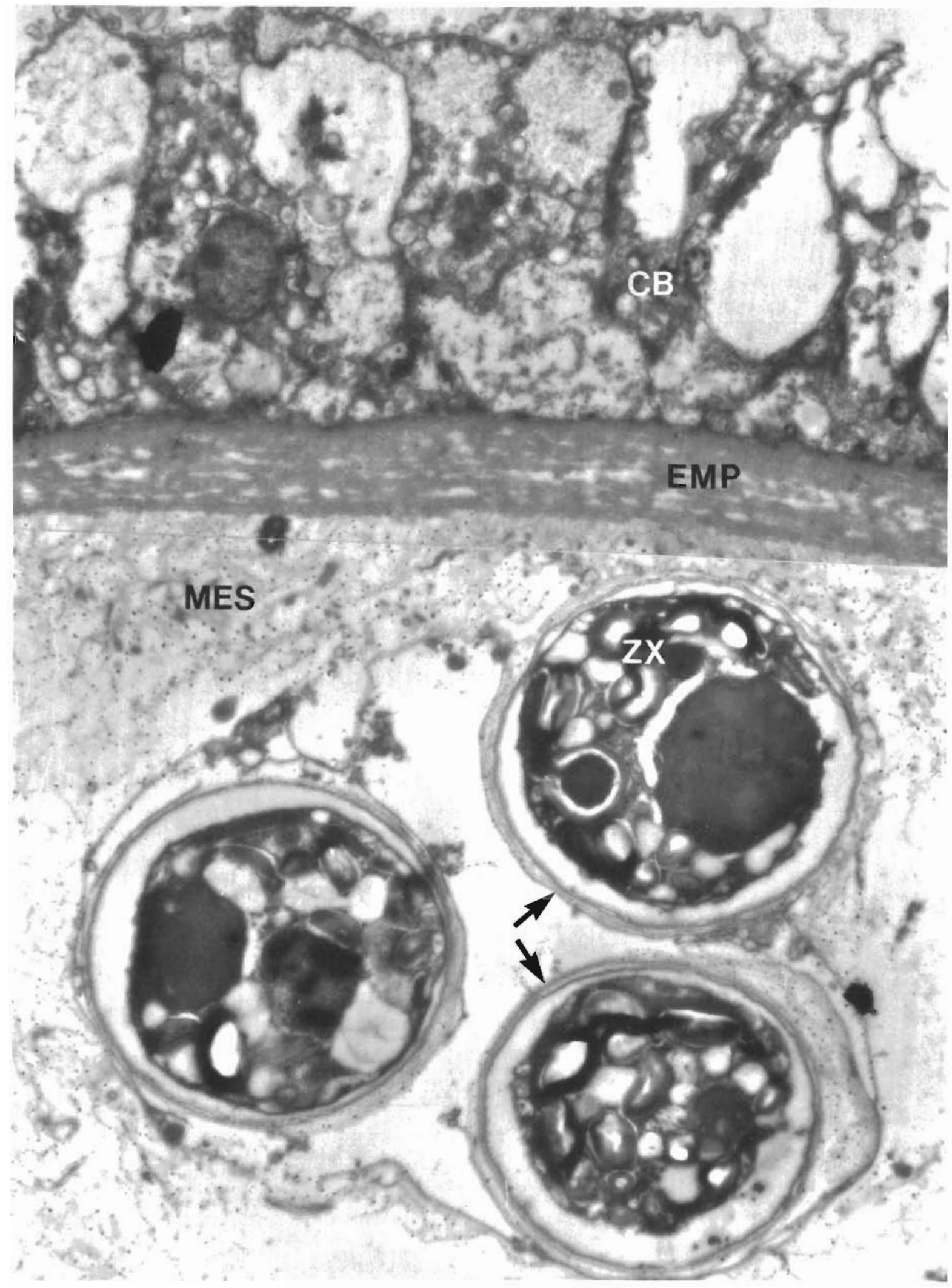

Fig. 2. Mastigias sp. Transmission electron micrograph of section through upper bell surface showing exumbrellar epitheliomuscular cells and algae in mesogleal spaces. Each alga is enveloped by several membranes (at arrows). CB: cell body; EMP: epitheliomuscular processes; MES: mesoglea; ZX: zooxanthellae. $6640 \times$ 


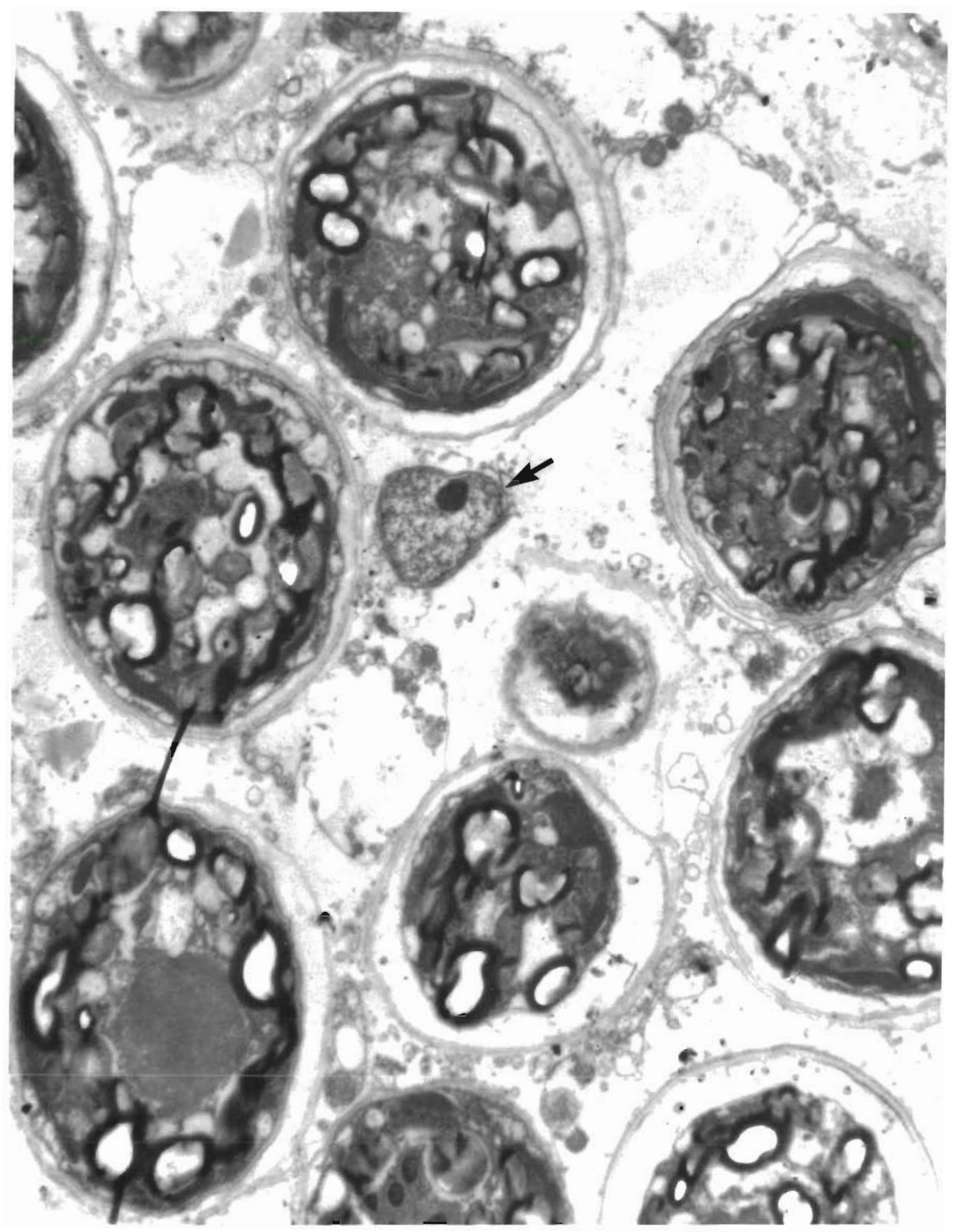

Fig. 3. Mastigias sp. As Fig. 2, showing animal cell nucleus (at arrow) among several algae in mesoglea. 6640x 
Specific growth rate of zooxanthellae $\left(\mu_{2}\right)$

Wilkerson et al. (1983) reported that zooxanthellae from freshly collected Mastigias sp. of similar size (6 to $8 \mathrm{~cm}$ ) exhibit a phased diel pattern of mitotic index (MI), with a maximum MI of 10.8 at $0400 \mathrm{~h}$. Using the appropriate formula of McDuff \& Chisholm (1982), Wilkerson et al. (1983) found the duration of cytokinesis $\left(t_{d}\right)$ to be $0.46 \mathrm{~d}$, and $\mu_{z}$ to be $0.1 \mathrm{~d}^{-1}$.

Since these data were derived from a limited size range of medusae, and we wished to extrapolate $\mu_{z}$ to zooxanthellae from all sizes of medusae, we sought additional data on $\mu_{z}$ over a greater host size range. It was not possible during our short field excursion to obtain diel curves for MI for all host sizes. Instead we measured MI of zooxanthellae from freshly collected medusae of different sizes, between 1600 and $2200 \mathrm{~h}$, when, in the phased diel MI pattern, the MI values were least variable over time and at their lowest values (see Wilkerson et al. 1983, Fig. 1). Therefore, values for $\mu_{2}$ derived from these MI data will represent minimum values. In this instance $\mu_{z}$ was calculated from a slight modification of the equation of McDuff \& Chisholm (1982) where

Table 1. Mastigias sp. Algae and medusa biomass parameters

\begin{tabular}{|c|c|c|c|c|c|c|}
\hline $\begin{array}{l}\text { Bell diam. } \\
\qquad(\mathrm{cm})\end{array}$ & $\begin{array}{c}\text { Total number } \\
\text { of algae } \\
\left(\times 10^{7}\right)\end{array}$ & $\begin{array}{l}\text { Mean algal } \\
\text { diam. } \\
(\mu \mathrm{m})\end{array}$ & $\begin{array}{c}\text { Total algal } \\
\text { carbon } \\
(\mathrm{mg})\end{array}$ & $\begin{array}{c}\text { Total algal } \\
\text { protein } \\
\text { (mg) }\end{array}$ & $\begin{array}{c}\text { Total medusa } \\
\text { protein } \\
\text { (mg) }\end{array}$ & $\frac{\text { Algal protein }}{\text { Medusa protein }}$ \\
\hline 2.20 & 0.36 & 9.51 & 0.25 & 0.16 & 3.49 & 0.05 \\
\hline 2.70 & 2.15 & 9.45 & 1.45 & 0.94 & 5.77 & 0.16 \\
\hline 3.30 & 2.40 & 9.37 & 1.59 & 1.03 & 9.45 & 0.11 \\
\hline 4.20 & 3.14 & 9.27 & 2.02 & 1.31 & 17.11 & 0.08 \\
\hline 4.30 & 4.55 & 9.25 & 2.92 & 1.89 & 18.30 & 0.10 \\
\hline 4.50 & 5.94 & 9.23 & 3.78 & 2.45 & 20.27 & 0.12 \\
\hline 4.60 & 8.30 & 9.22 & 5.27 & 3.41 & 21.40 & 0.16 \\
\hline 5.00 & 5.99 & 9.17 & 3.75 & 2.43 & 26.27 & 0.09 \\
\hline 5.00 & 8.03 & 9.17 & 5.03 & 3.25 & 26.27 & 0.12 \\
\hline 5.80 & 11.77 & 9.07 & 7.17 & 4.64 & 37.85 & 0.12 \\
\hline 5.80 & 7.90 & 9.07 & 4.81 & 3.11 & 37.85 & 0.08 \\
\hline 7.50 & 20.19 & 8.87 & 11.60 & 7.50 & 71.23 & 0.11 \\
\hline 8.00 & 35.27 & 8.81 & 19.90 & 12.88 & 83.43 & 0.15 \\
\hline 8.20 & 37.73 & 8.79 & 21.14 & 13.68 & 88.71 & 0.15 \\
\hline 9.00 & 30.00 & 8.69 & 16.34 & 10.57 & 111.54 & 0.09 \\
\hline 10.00 & 38.88 & 8.57 & 20.42 & 13.21 & 144.54 & 0.09 \\
\hline 10.00 & 58.13 & 8.57 & 30.53 & 19.75 & 144.54 & 0.14 \\
\hline 11.00 & 34.50 & 8.45 & 17.47 & 11.30 & 182.74 & 0.06 \\
\hline 12.00 & 67.60 & 8.33 & 32.98 & 21.34 & 226.35 & 0.09 \\
\hline 12.00 & 53.55 & 8.33 & 26.13 & 16.90 & 226.35 & 0.07 \\
\hline 13.50 & 110.70 & 8.15 & 51.03 & 33.01 & 302.43 & 0.11 \\
\hline 14.50 & 103.50 & 8.03 & 45.90 & 29.70 & 360.55 & 0.08 \\
\hline 15.00 & 98.68 & 7.97 & 42.92 & 27.77 & 391.91 & 0.07 \\
\hline 15.10 & 144.37 & 7.96 & 62.55 & 40.47 & 398.37 & 0.10 \\
\hline 16.00 & 95.85 & 7.85 & 40.08 & 25.93 & 459.34 & 0.06 \\
\hline
\end{tabular}

Table 2. Mastigias sp. Regression data for biomass parameters. Coefficients a and b and best fit selected after trial regressions of $y=a+b x$ (linear), $y=a x^{b}$ (power), $y=a+b \ln (\log a r i t h m i c) ~ o r ~ y=a e^{b x}$ (exponential). $\left(n=25\right.$ except for mitotic index and $\mu_{t}$ where $n=21 ; z x=$ zooxanthellae)

\begin{tabular}{|c|c|c|c|c|c|c|}
\hline \multicolumn{2}{|c|}{ Parameters } & \multicolumn{2}{|c|}{ Coefficients } & \multirow[t]{2}{*}{$\mathrm{r}$} & \multirow{2}{*}{$\begin{array}{l}\text { Best fit } \\
\text { curve }\end{array}$} & \multirow[t]{2}{*}{$\mathrm{p}$} \\
\hline$y$ & $\mathrm{x}$ & $\mathrm{a}$ & $\mathrm{b}$ & & & \\
\hline Medusa protein (mg) & Bell diameter $(\mathrm{cm})$ & 0.502 & 2.459 & 0.99 & Power & $<.001$ \\
\hline Zx number $\times 10^{7}$ & Bell diameter & 0.101 & 2.614 & 0.98 & Power & $<.001$ \\
\hline Zx number $\times 10^{7}$ & Medusa protein & 0.210 & 1.063 & 0.98 & Power & $<.001$ \\
\hline Zx diameter ( $\mu \mathrm{m})$ & Bell diameter & 9.730 & -0.113 & 0.81 & Linear & $<.001$ \\
\hline Zx protein/medusa protein & Bell diameter & 0.124 & -0.003 & 0.33 & Linear & ns \\
\hline Zx number/medusa protein & Bell diameter & 0.267 & -0.002 & 0.14 & Linear & ns \\
\hline Zx mitotic index $(\%)$ & Bell diameter & 2.171 & -0.058 & 0.62 & Linear & $<.01$ \\
\hline$\mu,\left(d^{-1}\right)$ & Zx diameter & 0.0001 & 2.656 & 0.65 & Linear & $<.01$ \\
\hline$\mu_{z}\left(d^{-1}\right)$ & Bell diameter & 0.0467 & -0.003 & 0.62 & Linear & $<.01$ \\
\hline
\end{tabular}




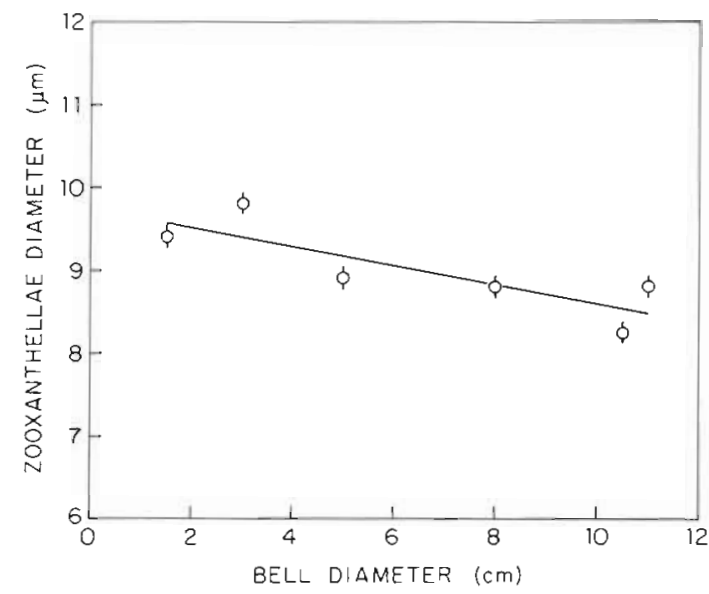

Fig. 4. Zooxanthellae diameter as a function of bell diameter. Each point is the mean of 100 measurements of zooxanthellae diameter. Vertical bars indicate $\pm \mathrm{SE}$ of the means. Regression data in Table 2

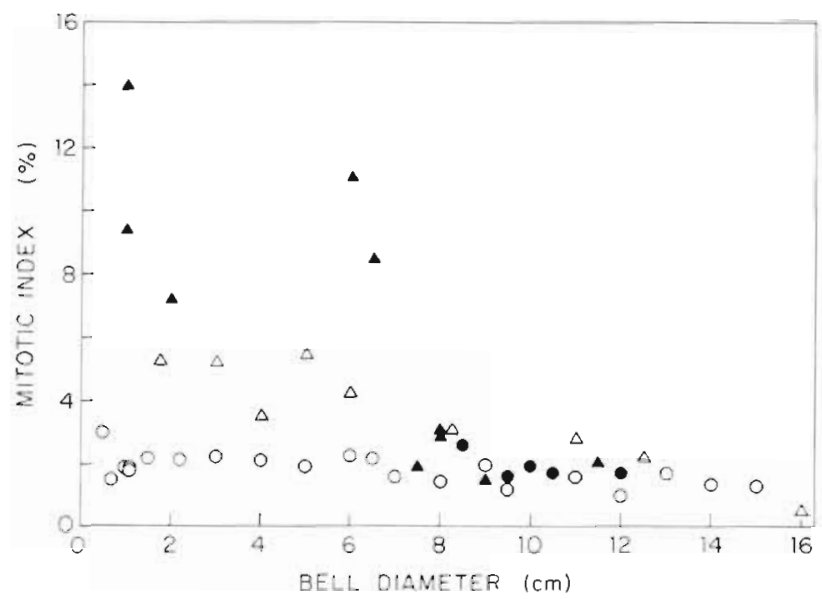

Fig. 5. Mitotic index (i.e. percentage of cells undergoing cytokinesis) of zooxanthellae as a function of bell diameter, showing the effect of increased maintenance of Mastigias sp. in the laboratory. (O) Freshly collected controls; ( $\Delta$ ) after maintenance for $1 \mathrm{~d} ;(\boldsymbol{\Delta}) 2 \mathrm{~d} ;(\bullet) 3 \mathrm{~d}$

$$
\mu_{z}=1 / t_{d} \ln \left(1+f_{m}\right)
$$

and $\mathrm{f}_{\mathrm{m}}$ is the average minimum daily MI. We used the value of $0.46 \mathrm{~d}$ for $t_{d}$.

In pursuit of these data we found generally that average daily minimum MI changed during maintenance of medusae in large outdoor holding tanks at ambient temperature and irradiance at the MMDC. Fig. 5 shows MI for populations of zooxanthellae in medusae held for 1,2 , and $3 \mathrm{~d}$ before sampling for measurement of $\mathrm{MI}$, compared to $\mathrm{MI}$ for zooxanthellae in controls (freshly collected). MI increased after $1 \mathrm{~d}$ in captivity, and to a greater extent in small medusae than in large ones. This trend is clearly borne out by medusae held for $2 \mathrm{~d}$, where zooxanthellae from large medusae show only a small increase in MI but those from small medusae exhibit a 4 to 7 -fold increase, representing growth rates as high as $0.28 \mathrm{~d}^{-1}$. Although medusae held after $3 \mathrm{~d}$ show no increase in zooxanthellae $\mathrm{MI}$, this is likely due to the fact that all of those medusae were relatively large $(>8 \mathrm{~cm}$ diam). In summary, the data show that extended maintenance causes an increase in mitotic indices of zooxanthellae in medusae $<8 \mathrm{~cm}$ diameter. This observation is important for interpretation of disparity in algal and host growth rates (see below).

MI and $\mu_{2}$ for zooxanthellae from freshly collected medusae as a function of host size are shown in Fig. 5 \& 6. Zooxanthellae growth rates averaged about $0.05 \mathrm{~d}^{-1}$ and decreased only slightly with increasing medusa size (Table 2). Since zooxanthellae size decreases with increasing medusa size (Fig. 4), it follows that, in Mas-

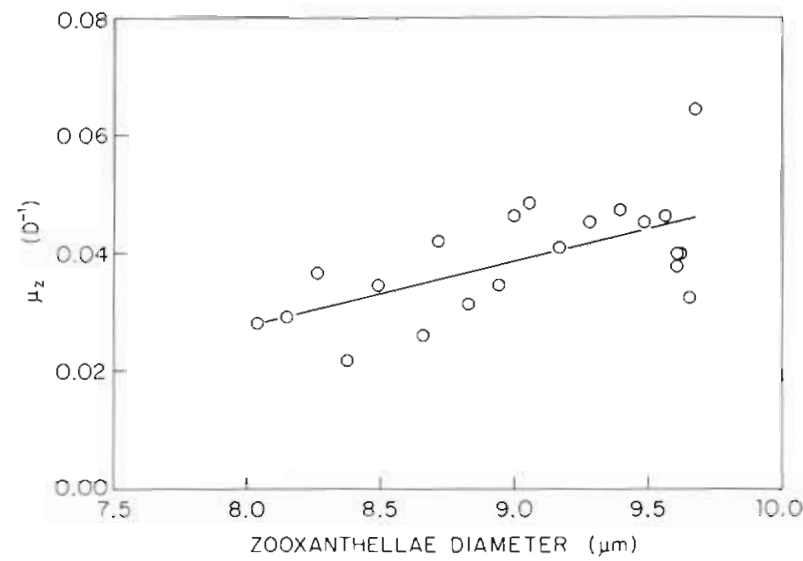

Fig. 6. Specific growth rate $\left(\mu_{2}\right)$ of zooxanthellae as a function of zooxanthellae diameter. Regression data in Table 2

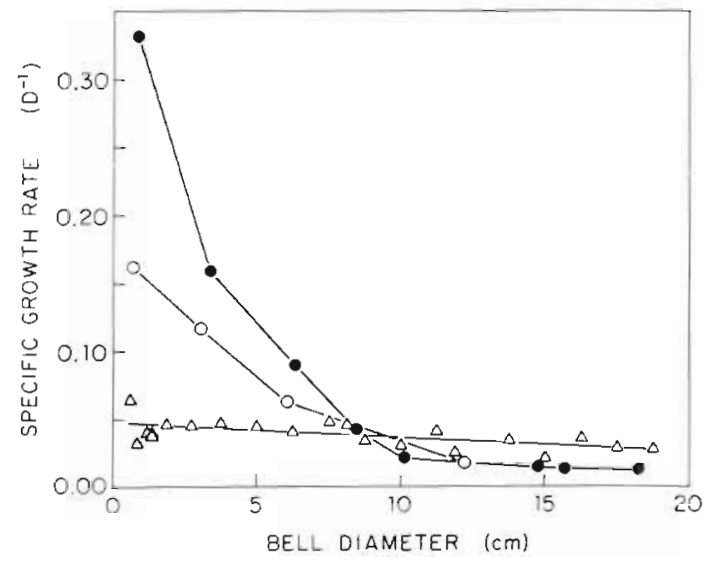

Fig. 7. Mastigias sp. Maximum ( $\bullet$ and mean (O) specific growth rates $\left(\mu_{a}\right)$ compared to specific growth rates $\left(\mu_{z}\right)$ of zooxanthellae $(\Delta)$ vs bell diameter 
Table 3. Mastigias sp. Maximum and mean specific growth rates calculated from data of Sugiura (1963)

\begin{tabular}{|c|c|c|c|c|c|}
\hline \multicolumn{2}{|c|}{$\begin{array}{l}\text { Linear regression constants } \\
\qquad \operatorname{diam}=a+b(\mathrm{age})\end{array}$} & Age (d) & Diameter $(\mathrm{cm})$ & Diameter +1 & $\mu_{d}\left(d^{-1}\right)$ \\
\hline \multicolumn{6}{|c|}{ Maximum growth rates $\left(\mu_{\mathrm{a}} \max \right)$} \\
\hline 0.02 & 0.03 & 14.3 & 0.45 & 0.48 & 0.062 \\
\hline-7.02 & 0.39 & 19.3 & 0.60 & 0.89 & 0.332 \\
\hline-12.73 & 0.62 & 25.0 & 2.85 & 3.39 & 0.159 \\
\hline-15.75 & 0.72 & 29.7 & 5.78 & 6.35 & 0.090 \\
\hline-3.74 & 0.36 & 32.9 & 8.10 & 8.46 & 0.043 \\
\hline-3.49 & 0.35 & 37.9 & 9.90 & 10.12 & 0.022 \\
\hline 2.79 & 0.23 & 53.6 & 15.45 & 15.67 & 0.014 \\
\hline- & - & 64.4 & 18.00 & 18.24 & 0.013 \\
\hline \multicolumn{6}{|c|}{ Mean growth rates ( $\mu_{\mathrm{a}}$ mean) } \\
\hline 0.02 & 0.03 & 14.3 & 0.45 & 0.48 & 0.062 \\
\hline-3.75 & 0.22 & 19.3 & 0.60 & 0.72 & 0.162 \\
\hline-7.30 & 0.35 & 28.6 & 2.70 & 3.06 & 0.117 \\
\hline-9.19 & 0.40 & 37.2 & 5.70 & 6.08 & 0.063 \\
\hline 0.21 & 0.22 & 52.9 & 12.00 & 12.22 & 0.018 \\
\hline- & - & 64.3 & 14.55 & 14.77 & 0.015 \\
\hline
\end{tabular}

tigias sp., as zooxanthellae get smaller, their growth rate decreases (Fig. 6).

\section{Specific growth rates of medusae $\left(\mu_{a}\right)$}

Maximum and mean specific growth rates of Mastigias sp. are listed in Table 3 and plotted in Fig. 7. After an initial lag phase (see Sugiura 1963, Fig. 6) very small medusae $(0.5$ to $3.0 \mathrm{~cm}$ diam) grew most rapidly $\left(\mu_{a} \max =0.34 \mathrm{~d}^{-1}\right)$. Thereafter, growth rate declined to a minimum of about $0.013 \mathrm{~d}^{-1}$ as size increased. Comparison of $\mu_{z}$ (minimum growth rates) and $\mu_{a}$ (maximum and mean growth rates) (Fig. 7) reveals that small medusae $(<8 \mathrm{~cm}$ diameter) grow faster than zooxanthellae while larger medusae ( $>8 \mathrm{~cm}$ diameter) grow marginally more slowly than their endosymbiotic algae.

\section{DISCUSSION}

The results of the present study show that the symbiotic medusa Mastigias sp. possesses abundant zooxanthellae in the mesoglea, probably within host cells. As host size increases, zooxanthellae abundance also increases proportionately with the result that the weight-specific density of zooxanthellae is independent of medusa size. Comparison of growth rates of host and algae measured independently suggests that maintenance of population density is most likely to occur in 2 ways; by facultative increase in growth rates of zooxanthellae in small medusae, and by expulsion or digestion of zooxanthellae in large medusae.

\section{Fine structure of the association}

Zooxanthellae are prevalent in many species of rhizostome medusae (Smith 1936). Studies of Uchida (1926) and Sugiura (1964) show that eggs and planulae of Mastigias papua do not have zooxanthellae. Algae are acquired by the scyphistoma larvae. By analogy with Cassiopeia xamachana scyphistomae, algae presumably enter the mouth and are phagocytized by cells of the endoderm (Fitt \& Trench 1983, Fitt 1984). At the onset of strobilation, zooxanthellae move from the endoderm to the mesoglea in amoeboid cells (Ludwig 1969, Colley \& Trench 1985). Uchida (1926) observed zooxanthellae in the canal system of $M$. papua ephyra larvae and noted their subsequent spread into the mesoglea. Although he noted zooxanthellae occasionally in cells of the gonad and exumbrellar and subumbrellar epithelia, the algae were mainly clustered in the mesoglea. This arrangement was confirmed in the present study (Fig. 1a,b), and by the observations of Muscatine \& Marian (1982) who noted that the algae occur in clusters of 12 to 200 cells, with about 50 such clusters per $\mathrm{mm}^{2}$ of bell surface. Smith (1936) and Ludwig (1969) observed algae in 'wandering cells' in the mesoglea, often in large numbers within a single wandering cell. In the present study, algae were observed in the mesoglea within a series of perialgal membranes, and in close proximity to animal cell nuclei. The observations and interpretation that the algae are intracellular, within vacuoles, and that more than one alga may occur within an animal cell in the mesoglea, are consistent with those of Smith (1936) and Ludwig (1969) on adult Cassiopeia. This interpretation does not exclude the possibility that some algae 
are extracellular. An intracellular locus for zooxanthellae provides scope for regulation of growth rate and maintenance of population density either by expulsion or digestion, since presumably these processes are mediated by the host cells.

\section{Biomass parameters}

There are few previous studies on size variation of zooxanthellae in symbiotic marine cnidarians. In corals from the Timor Sea, zooxanthellae size increases with depth (Titlyanov et al. 1980), while in Jamaican corals zooxanthellae size decreases with depth (Wilkerson et al. unpubl.). Smith (1984) found no significant correlation between zooxanthellae mean diameter and sea anemone biomass. In the present study, Mastigias sp. zooxanthellae decrease in size with increasing host size (Fig. 4), and the smaller cells have a lower specific growth rate (Fig. 6). This trend is opposite to the view that, at least for free-living phytoplankton, specific growth rate is inversely related to cell size (see review of Malone 1980). The reason for this variance with expectation is not known but may have something to do with host regulation of zooxanthellae growth rates.

Domotor \& D'Elia (1984) describe a bimodal sizefrequency distribution for zooxanthellae from Pacific corals and the giant clam Tridacna sp. The significance of such a distribution is not fully understood.

\section{Zooxanthellae population density}

Zooxanthellae-cnidarian symbioses can be characterized by a finite algal population density, ranging from about 3 to $23 \%$ of their total protein biomass (Muscatine 1980, Muller-Parker 1984, Smith 1984). The magnitude of algal population density may be influenced, in part, by ambient light, host nutrition, and host biomass (Drew 1972, Redalje 1976, Falkowski \& Dubinsky 1980, Svoboda \& Porrmann 1980, Dustan 1982, McCloskey \& Muscatine 1984, Muller-Parker 1984, Wilkerson et al. unpubl.). For example, algal densities negatively correlated with sea anemone polyp biomass have been reported by Steele (1976), Svoboda \& Pormann (1980), and Fitt et al. (1982), while densities independent of polyp size have been reported by Smith (1984) for Aiptasia tagetes from a high light environment. The zooxanthellae population density in Mastigias sp. is independent of medusa size and comprises about $10 \%$ of the protein biomass (see also Muscatine \& Marian 1982).

Even though algal protein biomass calculated from cell volume and $C: N$ ratio in this study compares well with previous estimates, the values depend, in part, on the accuracy of the $C: N$ analysis. The mean $C: N$ value for Mastigias sp. zooxanthellae was $9.66 \times 0.43$. This departure from the Redfield ratio of 6.6 needs explaining. Increased $\mathrm{C}: \mathrm{N}$ in late growth stages of cultured zooxanthellae was interpreted by Chang et al. (1983) and Domotor \& D'Elia (1984) as due to carbon-rich detritus included in the analyses, or to nitrogenlimited cells. Because of the watery and mucus-free nature of the Mastigias sp. homogenate, the zooxanthellae were easily isolated and noticeably free from extraneous debris. We believe that detrital carbon was minimal and not responsible for the relatively high $C: N$ value. Goldman et al. (1979) suggest that $C: N$ greater than 6.6 implies less than maximal growth rate, proably due to nutrient limitation. Indeed, growth rates of $0.1 \mathrm{~d}^{-1}$ are about $30 \%$ of the maximum rates observed in zooxanthellae after $2 \mathrm{~d}$ maintenance in the laboratory (Fig. 5). However, ammonium is abundant at the Eil Malk Lake chemocline (Hamner et al. 1982), and symbiotic medusae, which visit the chemocline periodically, are able to take up ammonium from the environment, even in the dark (Muscatine \& Marian 1982). At present the meaning of the moderately high $\mathrm{C}: \mathrm{N}$ ratio of Mastigias sp. zooxanthellae remains unresolved.

\section{Zooxanthellae growth rates}

Several previous studies present data on in situ growth rates of zooxanthellae in a single host or limited range of host sizes (Patton \& Burris 1983, Wilkerson et al. 1983, unpubl., Muscatine et al. 1984, 1985, Steen \& Muscatine 1984, Smith 1984). Smith (1986) was the first to evaluate algal growth parameters as a function of host size (age). He found that whereas juvenile and adult Aulactinia stelloides had zooxanthellae of equivalent size, the MI of zooxanthellae from juveniles was double that of adults. Thus MI, and presumably $\mu_{2}$, decreased with increasing host biomass. Fig. 5 \& 6 show that as host size increases, there is only a slight decrease in $\mu_{2}$ concomitant with a decrease in algal cell diameter. Zooxanthellae in the sea slug Pteraeolidia ianthina behave similarly (Hoegh-Guldberg et al. 1986). It is noteworthy that the opposite trend in MI vs cell size has been observed in zooxanthellae in Caribbean reef corals. In that case MI, and probably $\mu_{z}$, increase as zooxanthellae diameter decreases (Wilkerson et al. unpubl.).

Due to the nature of the sampling protocol in this study (see 'Results'), the minimum value of $\mu_{2}$ was estimated to be approximately $0.05 \mathrm{~d}^{-1}$. Had we been able to sample zooxanthellae over a diel cycle from each medusa size class, $\mu_{z}$ would probably have been 
close to $0.1 \mathrm{~d}^{-1}$, the value reported originally for Mastigias sp. by Wilkerson et al. (1983).

Collection of data on $\mathrm{MI}$ is labor intensive, and initially required maintenance of medusae over several days. It soon became apparent that MI increased with increasing maintenance in the laboratory, as shown in Fig. 5, and only in small specimens. The conditions which produce these high mitotic indices and concomitant high in situ growth rates of zooxanthellae are not known, nor do we know why they occur only in the smaller medusae. The observation is extremely important, however, since it shows that such conditions do exist.

Medusa growth rates $\left(\mu_{a}\right)$; comparison with $\mu_{z}$

There are a modest number of studies of growth rates of medusae (cf. Arai 1980) but little data on rhizostomes, particularly those with symbiotic zooxanthellae. The average specific growth rate $(\mu)$ of the rhizostome Rhizostoma octopus, calculated by Zaika (1972) from data of Thiel (1966, in Zaika 1972) was $0.03 \mathrm{~d}^{-1}$. Curiously, $\mu$ for $R$. octopus increased with age in specimens from 2.0 to $22.0 \mathrm{~cm}$ diameter, a trend opposite to expectations from general allometric growth data. In the present study, using the data of Sugiura (1963) for symbiotic Mastigias papua, $\mu_{a}$ decreased with age, with higher growth rates in juvenile medusae, and lower rates, comparable to the average for $R$. octopus, in medusae greater than about $8 \mathrm{~cm}$ diam

It should be emphasized that Mastigias sp. occurs not only in Eil Malk Lake but also in Palau Lagoon. Mastigias papua collected by Sugiura were probably of the lagoon type, so that the growth rates of his specimens may differ somewhat from those of Mastigias sp. from Eil Malk Lake.

Comparison of maximum and mean growth rates of Mastigias sp. with minimum zooxanthellae growth rates (Fig. 7) or even with presumed maximum zooxanthellae growth rates (i.e. $0.1 \mathrm{~d}^{-1}$ ) leads to the same conclusions. Small medusae grow faster than their zooxanthellae; large ones grow more slowly. The general implications of these growth rates are that algae and host are rarely growing at the same rate, except perhaps when medusae are about 6 to $8 \mathrm{~cm}$ diameter. The patterns predict that small rapidly growing medusae would outgrow their algal flora over short time periods. However, data in Table 2 imply that weight-specific population density is independent of medusa size. To account for the maintenance of a sizeindependent algal population density we conjecture that the zooxanthellae in Mastigias sp. have the ability to undergo short periods of very rapid growth, as shown in Fig. 5, probably during periods of rapid growth of small medusae. The situation is reminiscent of the fast-growing tips of a branching coral such as Acropora cervicornis, which have fewer zooxanthellae than the tissue along the branch length (Pearse \& Muscatine 1971). Growth rates of zooxanthellae from A. cervicornis, which average about $0.08 \mathrm{~d}^{-1}$ along the branch length, more than double at the tip to $0.19 \mathrm{~d}^{-1}$ (Wilkerson et al. unpubl.), presumably in response to stimuli provided by the rapidly growing axial polyp or to the increased habitat volume.

Larger medusae grow more slowly than their algae and thus need to regulate zooxanthellae population density to avoid being overgrown by them. Expulsion of zooxanthellae has been described by Smith (1936) in the rhizostome medusa Cassiopeia frondosa. Algae were described as entering the gastric canals at the base of the gastric filaments. We observed clumps of debris laden with zooxanthellae in small experimental containers in which Mastigias sp. was held for $1 \mathrm{~d}$. We take this as evidence for expulsion of zooxanthellae.

There is no evidence yet for digestion of zooxanthellae in these medusae. However, the occurrence of algae within host cells and the demonstration that lysosomes fuse with phagosomes containing algae in Cassiopeia xamachana scyphistomae (Fitt \& Trench 1983, Colley \& Trench 1985) suggests that such a regulatory mechanism is potentially possible.

Acknowledgements. This investigation was supported by a research grant (No. 2419) from the National Geographic Society. We thank the Micronesian Mariculture Demonstration Center for providing space and facilities, Mr. Francis Toribiong for diving support, Dr. E. H. Gladfelter for assistance with SEM, M. Eiserling for assistance with TEM, and O. Hoegh-Guldberg, G. Jason Smith, G. Steen, and C. Taylor for reviewing drafts of the manuscript.

\section{LITERATURE CITED}

Arai, M. N. (1980). Growth rates of Aequorea medusae. In: Tardent, P., Tardent, R. (ed.) Developmental and cellular biology of coelenterates. Elsevier Press, Amsterdam, p. 163-169

Chang, S. S., Prézelin, B. B., Trench, R. K. (1983). Mechanisms of photoadaptation in three strains of the symbiotic dinoflagellate Symbiodinium microadnaticum. Mar. Biol. 76: 219-229

Colley, N., Trench, R. K. (1985). Cellular events in the reestablishment of a symbiosis between a marine dinoflagellate and a coelenterate. Cell Tissue Res. 239: 93-103

Domotor, S. L., D'Elia, C. F. (1984). Nutrient uptake kinetics and growth of zooxanthellae maintained in laboratory culture. Mar. Biol. 80: 93-101

Drew, E. A. (1972). The biology and physiology of algainvertebrate symbiosis. II. The density of symbiotic algal cells in a number of hermatypic hard corals and alcyonarians from various depths. J. exp. mar. Biol. Ecol. 9: 71-75

Droop, M. (1963). Algae and invertebrates in symbiosis. In: Mosse, B., Nutman, P. (ed.) Symbiotic associations. Soc. 
Gen. Microbiol. Symp. No. 13., Cambridge Univ. Press, Cambridge, p. 171-199

Dustan, P. (1982). Depth-dependent photoadaptation by zooxanthellae of the reef coral Montastrea annularis. Mar. Biol. 68: 253-264

Falkowski, P. G., Dubinsky, Z. (1980). Light-shade adaptation of Stylophora pistillata, a hermatypic coral from the Gulf of Eilat. Nature, Lond. 289: 172-174

Fitt, W. K. (1984). The role of chemosensory behavior of Symbiodinium microadriaticum, intermediate hosts, and host behavior in the infection of coelenterates and molluscs with zooxanthellae. Mar. Biol. 81: 9-17

Fitt, W. K., Trench, R. K. (1983). Endocytosis of the symbiotic dinoflagellate Symbiodinium microadriaticum Freudenthal by endodermal cells of the scyphistomae of Cassiopeia xamachana and resistance of the algae to host digestion. J. Cell Sci. 64: 195-212

Fitt, W. K., Pardy, R. L., Littler, M. M. (1982). Photosynthesis, respiration and contribution to community productivity of a symbiotic sea anemone Anthopleura elegantissima. J. exp. mar. Biol. Ecol. 61: 213-232

Goldman, J. C., McCarthy, J. J., Peavey, D. G. (1979). Growth rate influence of the chemical composition of phytoplankton in oceanic waters. Nature, Lond. 279: 210-214

Hamner, W. M., Hauri, I. (1981). Effects of island mass: water flow and plankton pattern around a reef in the Great Barrier Reef Lagoon, Australia. Limnol. Oceanogr. 26: 1084-1102

Hamner, W. H., Gilmer, R. W., Hamner, P. P. (1982). The physical, chemical and biological characteristics of a stratified, saline sulfide lake in Palau. Limnol. Oceanogr. 27: 896-909

Hoegh-Guldberg, O, Hinde, R., Muscatine, L. (1986). Studies on a nudibranch that contains zooxanthellae. II. Contribution of zooxanthellae to animal respiration (CZAR) in Pteraeolidia ianthina with high and low densities of zooxanthellae. Proc. R. Soc. B. (in press)

Ludwig, F. (1969). Die Zooxanthellen bei Cassiopea andromeda Eschscholtz 1829 (Polyp-Stadium) und ihre Bedeutung für die Strobilation. Zool. Jb. Anat. 86: 238-277

McCloskey, R. L., Muscatine, L. (1984). Production and respiration in the Red Sea coral Stylophora pistillata as a function of depth. Proc. R. Soc. B. 222: 215-230

McDowell, E. M. (1978). Fixation and processing. In: Trump, B., Jones, S. (ed.) Diagnostic electron microscopy. Wiley, New York, p. 113-139

McDuff, R. E., Chisholm, S. W (1982). The calculation of in situ growth rates of phytoplankton populations from fractions of cells undergoing mitosis: A clarification. Limnol. Oceanogr. 27: 783-788

McLaughlin, J. J. A., Zahl, P. (1966). Endozoic algae. In Henry, S. M. (ed.) Symbiosis, Vol. 1. Academic Press, New York, p. 257-297

Malone, T C. (1980). Algal size. In: Morris, I. (ed.) The physiological ecology of phytoplankton. University of California Press, Berkeley, p. 433-463

Muller-Parker, G. (1984). Photosynthesis-irradiance responses and photosynthetic periodicity in the sea anemone Aiptasia pulchella and its zooxanthellae. Mar. Biol. 82: 225-232

Muscatine, L. (1980). Productivity of zooxanthellae. In: Falkowski, P. G. (ed.) Primary productivity in the sea. Plenum, New York, p. 381-402
Muscatine, L., Marian, R. E. (1982). Dissolved inorganic nitrogen flux in symbiotic and nonsymbiotic medusae. Limnol. Oceanogr. 27: 910-917

Muscatine, L., Falkowski, P., Porter, J., Dubinsky, Z. (1984). Fate of photosynthetically-fixed carbon in light and shade-adapted colonies of the symbiotic coral Stylophora pistillata. Proc. R. Soc. B. 222: 181-202

Muscatine, L., McCloskey, L. R., Loya, Y (1985). A comparison of the growth rates of zooxanthellae and animal tissue in the Red Sea coral Stylophora pistillata. Proc. 5th Int Coral Reef Symp. 6: 119-123

Patton, J. S., Burris, J. E. (1983). Lipid synthesis and extrusion by freshly isolated zooxanthellae (symbiotic algae). Mar. Biol. 75: 131-136

Pearse, V B., Muscatine, L. (1971). Role of symbiotic algae (zooxanthellae) in coral calcification. Biol. Bull. mar biol. Lab., Woods Hole 141: 350-363

Redalje, R. (1976). Light adaptation strategies of hermatypic corals. Pacif. Sci. 30: 212

Smith, G. J. (1984). Ontogenetic variation in the symbiotic associations between zooxanthellae (Symbiodinium microadriaticum Freudenthal) and sea anemone (Anthozoa: Actiniaria) hosts. Ph. D dissertation, Univ. of Georgia

Smith, G. J. (1986). Ontogenetic influences on carbon flux in Aulactinia stelloides polyps (Anthozoa, Actiniaria) and their endosymbiotic algae. Mar Biol. (in press)

Smith, H. G. (1936). Contribution to the anatomy and physiology of Cassiopeia frondosa. Carnegie Inst. Wash. Pap. Tort. Lab. 31: 17-52

Steele, R. D. (1976). Light intensity as a factor in the regulation of the density of symbiotic zooxanthellae in Aiptasia tagetes (Coelenterata, Anthozoa). J. Zool., Lond. 179 $387-405$

Steen, R. G., Muscatine, L. (1984). Daily budgets of photosynthetically fixed carbon in symbiotic zoanthids. Biol. Bull. mar. biol. Lab., Woods Hole 167: 477-487

Strathman, R. R. (1967). Estimating the organic carbon content of phytoplankton from cell volume or plasma volume. Limnol. Oceanogr. 12: 411-418

Sugiura, Y (1963). On the life-history of rhizostome medusae. I. Mastigias papua L. Agassiz. Annotnes zool. jap. 36: 194-202

Sugiura, Y (1964). On the life history of rhizostome medusae. II. Indispensability of zooxanthellae. Embryologia 8: $223-233$

Svoboda, A., Porrmann, T. (1980). Oxygen production and uptake by symbiotic Aiptasia diaphana (Rapp) (Anthozoa, Coelenterata) adapted to different light densities. In: Smith, D. C., Tiffon, Y. (ed.) Nutrition of the lower Metazoa. Pergamon Press, Oxford, p. 87-99

Titlyanov, E. A., Shaposhnikova, M. D., Zvalinski, V. I. (1980). Photosynthesis and adaptation of corals to irradiance. 1. Contents and native state of photosynthetic pigments in symbiotic microalga. Photosynthetica 14: 281-282

Uchida, T. (1926). The anatomy and development of a rhizostome medusa, Mastigias papua L. Agassiz with observations on the phylogeny of Rhizostomae. J. Fac. Sci. Tokyo Univ., Sect. IV, Zool. 1. 45-95

Wilkerson, F. P., Muller-Parker, G., Muscatine, L. (1983). Temporal patterns of cell division in natural populations of endosymbiotic algae. Limnol. Oceanogr 28: 1009-1014

Zaika, V E. (1972). The growth of ctenophores and medusae. Zool. Zh. 51: 179-188 